\title{
Adaptation of Reputation Tracker Corporate Reputation Measurement Tool (RepTrak) to Turkish: Validity and Reliability Study
}

\section{Research Article}

\section{Muammer ERGUN ${ }^{1}$}

${ }^{1}$ Kastamonu University, Faculty of Education, Department of Educational Science, Kastamonu, Turkey, ORCID: 0000-0003-1066-8066

To cite this article: Ergun, M. (2021). Adaptation of reputation tracker corporate reputation measurement tool (Rep Trak) to Turkish: Validity and reliability study, International Online Journal of Educational Sciences, 13(1), 33-52.

\begin{tabular}{ll} 
ARTICLE INFO & ABSTRACT \\
\hline Article History: & $\begin{array}{l}\text { The purpose of this study is to adapt the reputation measurement tool Rep Trak, which is widely } \\
\text { used all over the world to determine the reputation of organizations, into Turkish. Equivalence } \\
\text { Received: 01.01.2020 }\end{array}$ \\
studies of the original scale consisting of 23 items and seven factors were conducted. In the first stage, \\
the scale was applied to a sample group of 116 people, and a four-factor structure consisting of 23 \\
items emerged. The reliability coefficient of this structure was found to be 0.928 . In the second study, \\
a second application was applied to a sample group of 450 people. Exploratory factor analysis (EFA) \\
was performed with the data obtained. As a result of this analysis, it was found that all 23 items \\
remained in the scale, but the number of factors dropped to five. It has been observed that EFA results \\
are in parallel with the studies in the literature. The total variance explained by the five factors as a \\
result of EFA was found to be 52.816. In the third stage, confirmatory factor analysis (CFA) was \\
performed on the data obtained from a different study group of 264 people. As a result of CFA, it \\
was found that the goodness of fit values were within acceptable limits. The calculated reliability \\
coefficient was found to be 0.926. These results showed that the Turkish form of the scale is a valid \\
and reliable measurement tool and can be used in scientific studies about the reputation of higher \\
education institutions.
\end{tabular}

C 2021 IOJES. All rights reserved

Keywords:

Reputation, reputation measurement, the reputation of educational institutions, RepTrak

\section{Introduction}

It is known that management practices have emerged since human beings started to organize in large or small groups in history. Although management practices are so old, the acceptance of management as a

${ }^{1}$ Corresponding author's address: Kastamonu Üniversitesi, Eğitim Fakültesi, Eğitim Bilimleri Bölümü.

Telephone: 03662803418

e-mail: mergun@kastamonu.edu.tr

DOI: https://doi.org/10.15345/iojes.2021.01.003 
science and studies on it started after the industrial revolution. When the years in which organization and management studies started to enter the literature, a period of 50 years between 1875 and 1925 can be defined as a period in which studies on organization and management gradually began to theorize. After the first quarter of the 20th century, studies in the field of organization and management gained momentum, and a period called post-modern was started in the 1970s. In the 21st century, due to the rapid change of information and technology in the world, organization and management theories have started to cooperate with different disciplines to increase the efficiency and effectiveness of the organization. As a result of this, the concept of corporate reputation has entered the field of interest of organization management. It is seen in the literature that studies on reputation are done for the last 50 years in the world and 25 years in Turkey (Açıkgöz, \& Karakaya, 2018; Balay, Kaya, \& Yıldırım, 2017; Baygül-Özpınar, 2008; Çabuk, 2017; Çınar \& Basim, 2019; Dinçel, 2012; Ergün, Akcaoğlu, \& Ünver, 2018; İnce \& Tosun, 2015; Kaplan, 2018; Karakaya-Şatır, 2013; Özalp, Tonus, \& Geylan, 2010).

When the development of the concept of reputation in the historical process is examined, although it is derived from the Latin verb "reputare", it was used to mean "reckon" (to think, to count, to account) in the 14th century. In this sense, reputation is defined as "an evaluation made by a person for another person or institution" (Dowling, 2016). In the Far East, especially in Chinese, reputation is defined with "Lian", which means humility and "mian-zi", which means self-respect and status, as two aspects of human beings. These two aspects can be lost by negative behaviors of a person (Jackson, 2004), as well as gained by people's own behaviors. When the definitions of the concept of reputation are examined, it is seen that in the Cambridge Dictionary, it is defined as "the opinion formed by people about a person or thing, based on their past behaviors or characters". In the dictionary of the Turkish Language Association, reputation which is Arabic, is defined as "respectability, being reliable in paying debt and credit." Based on dictionary definitions, reputation can be defined as the perception of trust created by people or institutions, depending on their past behaviours and taking into account their characteristics.

The concept of reputation, which was originally used for individuals, has started to be used for organizations over time. The literature on corporate reputation is quite extensive and covers many disciplines (Barnett, \& Pollock, 2012; Cabral, 2016). These disciplines include organizational management, public relations, sociology, psychology, economics, communication, advertising, marketing. As a result of an interdisciplinary approach adopted in corporate reputation research from psychology to management in recent years, a number of different concepts have emerged regarding reputation. Reputation is the mental picture of the organization created by stakeholders (De Roeck, Maon, \& Lejeune, 2013). Reputation is the perceptions of stakeholders about an organization's ability to show value to its environment (Petkova, 2012). Experts generally express reputation as a reflection of a collective view of individual perceptions (Barnett, Jermier, \& Lafferty, 2006; Tischer, \& Hildebrandt, 2014; Walker, 2010; Wartick, 1992).

Corporate reputation is one of the main factors that enable organizations to compete with other organizations in the same sector and keep organizations alive and develop. Today, when products or services are very similar to each other, it is particularly difficult to stand out from the organizations that produce the same product or service and to get the leadership of the sector. Because the features of the products or services are almost the same, in an environment of similar characteristics, organizations can compete with their competitors only through corporate reputation (Ergün, 2017). Studies have revealed that 9 out of 10 customers consider corporate reputation when choosing between similar quality and products (Mackiewicz, 1993).

Fombrun and Van Riel (1997) defined corporate reputation as the actions of the organization in the historical process and the value-creating effects of these actions on different stakeholders. Dowling (2000) has tried to explain corporate reputation with values such as responsibility, truth, honesty and integrity. These values also constitute the image of the organization. The image of the organization perceived by the 
environment is the main factor that determines the reputation of the organization. Similarly, Weiss, Anderson, and Maclnnis (1999) tried to explain corporate reputation based on values. They expressed it as an emotional value that emerges as a result of the evaluation of the product or service offered to the environment by the customers.

Some authors, on the other hand, made an evaluation-based explanation. Corporate reputation is an assessment specific to an organization used by the followers of the organization as the quality of the product or service and possible signs of behavior in cases where there is no more specific information or when accessing information is too costly (Devers, Dewett, Mishina, \& Belsito, 2009). Corporate reputation represents the knowledge and feelings individuals have about an organization (Hardeck \& Hertl, 2014). Corporate reputation is the collective assessment of all stakeholders about an organization's credibility, consisting of the character that influences their trust and support decisions (Van Der Merwe, \& Puth, 2014). It reflects socially accepted standards about the importance of quality offered by the organization (Kennedy, Chok, \& Liu, 2012). The reputation of an institution is an intangible entity that is based on the recognition of the organization's high quality in its capabilities and outputs by broad social segments (Pfarrer, Pollock, \& Rindova, 2010).

Although the conceptual framework of the question of "what reputation is" is given in the explanations above, it will be useful to add one more definition to understand organizational reputation better. This definition is the sum of the perceptions formed by the stakeholders of the organization as a result of their observations about the organization rather than the inherent characteristics of the organizations (VidaverCohen, 2007). However, the differentiation of individual perceptions that make up this total perception should not be overlooked. Studies show that organizational reputation varies in line with expectations among stakeholder groups (Bromley, 2002). While creating perceptions, some stakeholders may consider the price of the product or service, some quality, and some others think about both criteria. Others consider the organization's backing of the product or service after it is marketed, while others consider easy accessibility. Different stakeholder groups may consider whether the organization protects the environment while producing the product or service. For internal stakeholders, this situation can be completely different. They can contribute to building the reputation of the organization by observing many different factors such as assurance of the future, wages, environment and management.

It is possible to talk about different assessment tools that measure corporate reputation, which is very important for institutions to survive. Most of these tools are product and brand-focused assessment tools created in the USA. The four commonly used of these are as follows (Van Riel, \& Fombrun, 2007):

1. Brand Value Measurement Tool: Young and Rubikam advertising agency developed it in 1993.

2. America's Most Admired Companies Measurement: It has been regularly applied every year since 1982 by Fortune magazine.

3. Reputation Coefficient Measurement Tool: Developed by Harris-Fombrun. It has been used to measure corporate reputation in 26 countries since 1996.

4. RepTrak ${ }^{\mathrm{TM}}$ : It has been designed by the Reputation Institute to monitor and analyze corporate reputation since 2005 .

In this study, a Turkish adaptation study of the scale named RepTrak ${ }^{\mathrm{TM}}$ was conducted. The adapted scale is widely used in international studies and many different cultures like in Italy, Spain, Thailand, USA, China, Portugal, Greece, England and Turkey (Christakou \& Klimis, 2014; Fombrun \& Pan, 2006; Luisa, Valeria, \& Nicola, 2018; Pitpreecha, 2013; Ramalho, \& Matos Resende, 2016; Ruiz, Esteban, \& Gutiérrez, 2014a, 2014b; Ruiz, García, \& Revilla, 2016; Ural \& Erim, 2010). 
Corporate reputation is an important criterion used in determining the rank of organizations in the sector league within their area of interest. This also emerges as an inevitable factor in achieving sectoral standing, competitiveness and development. Although the measurements of reputation are carried out frequently in order to ensure recognition in the sectors in which the goods-producing organizations are involved, it can be seen when the dates of the literature mentioned in the following paragraph are examined, that until recently, the measurement of the reputation of the organizations that produce services in general and the educational organizations in particular, and more specifically, the higher education institutions was not regarded seriously.

In this context, the determination of corporate reputation has become a necessity for higher education institutions at the top of educational institutions where competition is increasing. As an education and science production institution, the reputation of universities is questioned by different stakeholders at both national and global levels. These stakeholders can be counted as other universities, academicians, university students, high school students, parents of students, university administrators, legislators, university supervisory units, overseas higher education institutions, overseas students, labor market. These stakeholders can be increased or limited to those who are directly interacting. Since the main factor determining the reputation of institutions is their stakeholders, it cannot be ignored that higher education institutions should be competent in reputation management from the lowest level managers to the highest-level managers.

It has long been recognized that organizations with good reputations have valuable assets. This is often known as the "goodwill" value of the organization's brand or the loyal customers' protecting the organization (Shapiro, 1983). It is seen that there are different articles in the literature about the argument saying that reputation assets of the organizations in the last quarter of the 20th century can generate income for the organizations in the future (Ayyildiz, Yilmaz, \& Baltaci, 2021; Weigelt, \& Camerer, 1988; Wilson, 1985).

Although there are measurement tools that can measure corporate reputation in the Turkish literature, there are a few scales that can measure the institutional reputation of educational institutions. However, it can be said that these studies also have some limitations, as stated in the following paragraphs.

When the literature originating in Turkey is observed, it is seen that some studies are done about the reputation scale. However, among the only few studies that were accessible, it was observed that four studies were reputation studies related to higher education. Other studies concern different institutions. If these institutions are to be summarized, health organizations (İnce \& Tosun, 2015), tourism sector (Cianci, \& Kaplan, 2010), automotive sector (Aydem-Çiftçioğlu, 2008), non-governmental organizations (Çabuk, 2017), commercial organizations of companies in general (Baygül-Özpınar, 2008), they are studies that measure customer-based reputation (Dinçel, 2012), measuring social and financial reputation (Tonus \& Tez-Özkan, 2013). Although the sector which the study by Geçikli, Erciş, and Okumuş (2016) was conducted based on was not disclosed in the study, the statement of one of the leading institutions of Turkey and the context indicates that it was not an educational institution. In a study conducted by Çınar and Basim (2019), the scale developed by Mael and Ashforth (1992) to measure organizational reputation was carried out using data obtained from different public and private institutions. This scale is one-dimensional.

When the scale adaptation or development studies on educational organizations are examined, it is seen that studies are based on academic organizations (Balay et al., 2017; Karakaya-Şatır, 2013; Özalp et al., 2010) was conducted with only the data collected from internal stakeholders. The scale adopted by Açıgöz and Karakaya (2018) is a corporate adaptation study of reputation scale developed by Ingenhoff and Sommer (2010).

The importance of this scale adaptation study becomes apparent when the literature information given above is analyzed. If the literature is grouped, we can see the work done apart from educational institutions 
in the first group. In the second group, it is possible to see studies on educational institutions. However, it is possible to divide these studies into two subgroups, too. One of the subgroups is the studies conducted with scales developed by different people, except for the RepTrack scale developed by Ponzi, Fombrun, and Gardberg (2011). Another sub-group is the scales that were either adapted or developed only according to the opinions of "internal stakeholders." This study was carried out in a way that higher education institutions can use and by considering both internal and external stakeholders. In this respect, it differs from all other studies. The purpose of the research is to privatize the RepTrak reputation measurement tool, which the Reputation Institute developed in order to measure the reputation of general institutions and adapt it to higher education institutions and Turkish culture. In this context, the purpose of this study is to test the adaptability of the RepTrak reputation assessment tool to Turkish in general and to higher education institutions in particular.

\section{Limitations}

The findings of this study were limited by the statistical treatment of data collected and the inherent limitations of the instrument. It is also limited to the data collected from a province in the Western Black Sea region. On the other hand, it is almost impossible to reach a university's graduates, one of the stakeholders, without a graduate tracking system. Thus, the graduates were excluded from the study because the university where the study was conducted did not have a graduate tracking system. It is necessary to take these limitations into consideration while generalizing the research findings.

\section{Method}

In this section, information is given about the research model, study group, data collection tool, data collection and data analysis.

\section{Research Model}

In the study, it was aimed to adapt a scale that measures the reputation level of the university based on the perceptions of the internal and external stakeholders of the university, tradespeople, senior high school students, university students and university employees. In this direction, a descriptive survey model, one of the quantitative research designs, was used. The descriptive survey model is used in studies that aim to explain an existing phenomenon as it exists (Fraenkel, Wallen, \& Hyun, 1993). Furthermore, within the scope of the research, the principles developed by the International Test Commission (ITC) in 1993 and the final version (Version 2.4), were used in the process of adapting the RepTrak measurement tool to Turkish.

\section{Study Group}

The study group of the research consists of the participants residing in the central district of a province located in the Western Black Sea Region. These participants are high school students, tradespeople, civil servants, and students studying at the university in that province, who are the university's stakeholders to determine the university's institutional reputation in the city where the study was conducted. Data were collected over three separate study groups based on the university's internal and external stakeholders. The first study group consists of 116 participants, the second study group 450 and the third study group consists of 264 participants. (Table 1). The samples of all three groups were determined using stratified and simple random sampling techniques, one of the probabilistic sampling techniques. In the stratified sampling technique, the layers that make up the population are represented in the sample group directly to the population. In the simple random sampling technique; the probability of each stratum selected for the sampling to be included in the sample is equal (Büyüköztürk, Çakmak, Akgün, Karadeniz, \& Demirel, 2016). A separate layer from internal stakeholders (university staff and students) and external stakeholders (high school students and tradesmen) were accepted with the stratified sampling method. There are three separate study groups in the study, two for Exploratory Factor Analysis (EFA) and one for Confirmatory Factor 
Analysis (CFA). Participants in the first study group ( $n=116$ ) were $48.3 \%$ women, $51.7 \%$ men, and in the second study group $(n=450), 51.1 \%$ men and $48.9 \%$ women. The third study group $(n=264)$ included $51.1 \%$ male and $48.9 \%$ female participants (Table 1 ).

Table 1. Sample distribution

\begin{tabular}{llllllll}
\hline \multirow{2}{*}{ Variables } & & \multicolumn{2}{c}{ Group 1 } & \multicolumn{2}{c}{ Group 2 } & \multicolumn{2}{c}{ Group 3 } \\
\multirow{2}{*}{ Gender } & n & \% & $\mathbf{n}$ & $\mathbf{\%}$ & $\mathbf{n}$ & \% \\
\hline \multirow{2}{*}{ Occupationale } & 56 & 48.3 & 220 & 48.9 & 129 & 48.9 \\
\cline { 2 - 8 } & Male & 60 & 51.7 & 230 & 51.1 & 135 & 51.1 \\
\cline { 2 - 8 } & University Student & 36 & 31.0 & 161 & 35.8 & 89 & 33.7 \\
\cline { 2 - 8 } & High school student & 29 & 25.0 & 94 & 20.9 & 38 & 14.4 \\
\cline { 2 - 8 } & Civil Servant & 26 & 22.4 & 88 & 19.6 & 66 & 25.0 \\
\cline { 2 - 8 } Total & Tradespeople & 25 & 21.6 & 107 & 23.8 & 71 & 26.9 \\
\hline
\end{tabular}

\section{Data Collection Tool}

The original Rep Trak ${ }^{\mathrm{TM}}$ Reputation Tracker scale by the Reputation Institute (2005) consists of 7 factors and 23 items. It has been prepared to measure the corporate reputation of organizations operating at the sector level. One of the dimensions is called "Product/Service." This factor is expressed as the dimension in which whether the elements offered by the organizations are of high quality and have a value is determined. In addition, in this dimension, perceptions are evaluated based on the level of meeting customer needs (Dawar, \& Parker, 1994; Fombrun, Ponzi, \& Newburry, 2015; Lange, Lee, \& Dai, 2011). Another factor is named "Innovation" and is a stakeholder assessment that is considered to be an essential capital of an organization (Fang, Palmatier, \& Grewal, 2011), about whether it has the ability to adapt the organization and its products/services to innovation and developing technology (Fombrun et al., 2015).

The third factor is named as "Management." As explained by Davis (2005) as the structures and processes that hold the power control of organizations and find resources and distribute them among units in line with the objectives, management is seen as an important component in managing corporate reputation (Casado, Peláez, \& Cardona, 2014). From this point of view, the management dimension is related to whether organizations are evaluated in ethical, fair and transparent ways by their stakeholders (Fombrun et al., 2015).

The fourth factor is "Workplace." According to Fombrun et al. (2015), the workplace factor is the evaluation by the perceptions of stakeholders of the practices to create an environment with concerns for employees and treat and reward them fairly and equally. On the other hand, "Social Responsibility," which is the fifth factor, has been indicated as one of the main factors of corporate reputation by Lange et al. (2011). The social responsibility dimension of the scale is the evaluation of whether the organization is an environmentally friendly organization, supports environmental activities and contributes positively to society in this regard according to stakeholder perceptions (Fombrun et al., 2015). The "Leadership" dimension of the scale expresses the evaluation of the perception that managers can support organizations by having a perfect vision (Fombrun et al., 2015). The last factor is expressed as "Performance" and is determined based on financing (Donaldson \& Preston, 1995; Waddock \& Graves, 1997; Walsh, Weber, \& Margolis, 2003).

The original scale was prepared in accordance with a five-point Likert type answering. The lowest score to be obtained from the entire scale is 23 , and the highest score is 115 . While 115 points indicate the situations where the reputation is the highest, 23 points indicate that the organizational reputation is very low. A score of 53.66 points and below indicates a "low level" reputation, a score between 53.67 and 84.32 indicates a "medium-level" reputation, and 84.33 points and above indicates a "high level" reputation. In terms of the factor levels, 9.33 and below in the product-service dimension indicates "Low level" reputation, 9.33 to 14.66 
points indicates "medium level" reputation and 14.67 points and above indicates "high level" reputation. In the innovation dimension, 7 points and below indicate "low-level" reputation, 7.01-11.00 points indicate "medium level" reputation, and 11.01 points and above indicate "high level" reputation. In the ManagementWorkplace dimension, 14 points and below indicates "low-level" reputation, 14.01-22.00 points indicate "medium level" reputation, and 22.01 and above indicate "high level" reputation. In the social responsibility dimension, 9.33 points and below indicate "low level" reputation, 9.34-14.66 points indicate "medium level" reputation, and 14.67 points and above indicate "high level" reputation. In the Leadership-Performance dimension, 14 points and below indicates "low-level" reputation, 14.01-22.00 points indicate "medium level" reputation, and 22.01 points and above indicate "high level" reputation.

\section{Data Collection Process}

A separate sample group was formed for each study group for data collection. In all three groups, data were collected from sample groups through a questionnaire consisting of two parts. The data were collected by filling in the questionnaires face to face from senior high school students, university students, tradesmen and university employees in the vicinity of the university campus.

\section{Data Analysis}

In the analysis of the data, after calculating the Pearson correlation coefficient between the Turkish and English forms for linguistic equivalence, the t-test of the related sample was conducted to determine whether there was a significant difference between the Turkish and English forms. As a result of the normality test of the distribution for the collected data, it was found that the Skewness values were between -.30 and +.17 , and the Kurtosis values varied between -.51 and -.94 . Since these data are between -1 and +1 , the distribution is assumed to be normal. Then, Exploratory Factor Analysis (EFA) and Cronbach's Alpha reliability coefficient was calculated to examine the construct validity of the scale on the second different sample, and the Pearson correlation coefficient was calculated to determine the interdimensional relations. Finally, Confirmatory Factor Analysis (CFA) was performed on a third different sample.

\section{Findings}

\section{Reliability-Related Results}

Linguistic Equivalence. To ensure the linguistic equivalence of the scale, the Rep Trak scale was first translated from English to Turkish by an expert. The items in the form translated into Turkish and the original scale items were examined in terms of semantic, idiomatic, experiential and conceptual aspects by three linguists using the brainstorming technique, and the scale was finalized. The translated scale was put into practice in order to determine the linguistic equivalence statistically. At this stage, the bilingual group pattern was adopted, and the original scale and the Turkish form were applied, at two different times, to 25 English teachers working in high schools in X provinces in the Western Black Sea Region. In order to provide statistical evidence for the linguistic equivalence of the original form and the adapted form of the scale, the Pearson product-moment correlation coefficient for consistency between the results and the correlated samples t-test was used to test whether there was a difference between the two sets of scores. As a result of this calculation, correlation coefficients varying between 0.71 and 0.95 were found. When the difference between the two data was tested, as shown in Table 2, no statistically significant difference was found between the Turkish and English applications in all 23 items ( $p>0.05)$. Accordingly, it can be said that the translation process of the scale was successfully completed, and linguistic equivalence was achieved between the items. The scale was adapted to education in the next stage and was given to 2 domain experts to examine them. In line with the recommendations of the experts, the educational institutions' form of the scale was finalized. 
Table 2. Correlated sample t-test and the correlation between Turkish and English forms

\begin{tabular}{|c|c|c|c|c|c|c|c|c|c|c|}
\hline \multirow{2}{*}{$\begin{array}{l}\text { Item } \\
\text { No }\end{array}$} & \multirow{2}{*}{$\mathbf{n}$} & \multicolumn{2}{|c|}{ Turkish Form } & \multicolumn{2}{|c|}{ English Form } & \multirow{2}{*}{$\mathrm{Sd}$} & \multirow{2}{*}{$\mathbf{F}$} & \multirow{2}{*}{$\mathbf{t}$} & \multirow{2}{*}{$\mathbf{p}$} & \multirow{2}{*}{$\mathbf{r}$} \\
\hline & & $x$ & Ss & $x$ & Ss & & & & & \\
\hline 1 & 25 & 3.40 & 1.22 & 3.44 & 1.04 & 48 & .66 & -0.12 & 0.90 & .74 \\
\hline 2 & 25 & 3.36 & 1.04 & 3.32 & 1.07 & 48 & .01 & 0.13 & 0.89 & .83 \\
\hline 3 & 25 & 3.40 & 1.08 & 3.48 & 0.96 & 48 & .26 & -0.27 & 0.78 & .89 \\
\hline 4 & 25 & 3.20 & 1.08 & 3.16 & 1.03 & 48 & .32 & 0.13 & 0.89 & .91 \\
\hline 5 & 25 & 3.36 & 1.11 & 3.32 & 1.22 & 48 & .28 & 0.12 & 0.90 & .77 \\
\hline 6 & 25 & 3.16 & 1.46 & 3.08 & 1.29 & 48 & .61 & 0.21 & 0.83 & .92 \\
\hline 7 & 25 & 3.00 & 0.91 & 3.20 & 1.00 & 48 & .38 & -0.74 & 0.46 & .78 \\
\hline 8 & 25 & 3.08 & 1.15 & 3.28 & 1.24 & 48 & .59 & -0.59 & 0.55 & .78 \\
\hline 9 & 25 & 3.08 & 1.25 & 2.88 & 1.23 & 48 & .01 & 0.57 & 0.57 & .95 \\
\hline 10 & 25 & 3.36 & 1.32 & 3.20 & 1.35 & 48 & .01 & 0.42 & 0.67 & .94 \\
\hline 11 & 25 & 3.52 & 1.19 & 3.28 & 1.20 & 48 & .07 & 0.71 & 0.48 & .93 \\
\hline 12 & 25 & 3.36 & 1.15 & 3.16 & 1.21 & 48 & .02 & 0.60 & 0.53 & .94 \\
\hline 13 & 25 & 3.52 & 1.12 & 3.36 & 1.22 & 48 & .16 & 0.48 & 0.63 & .89 \\
\hline 14 & 25 & 3.48 & 1.00 & 3.72 & 0.94 & 48 & .03 & -0.88 & 0.38 & .86 \\
\hline 15 & 25 & 3.36 & 1.04 & 3.48 & 1.19 & 48 & .52 & -0.38 & 0.70 & .90 \\
\hline 16 & 25 & 3.92 & 0.76 & 3.68 & 1.03 & 48 & 2.05 & 0.94 & 0.35 & .82 \\
\hline 17 & 25 & 3.36 & 0.99 & 3.48 & 1.05 & 48 & .07 & -0.42 & 0.67 & .83 \\
\hline 18 & 25 & 3.24 & 1.01 & 3.12 & 1.13 & 48 & .06 & 0.40 & 0.69 & .92 \\
\hline 19 & 25 & 2.88 & 1.13 & 3.04 & 1.14 & 48 & .02 & -0.50 & 0.62 & .91 \\
\hline 20 & 25 & 2.96 & 1.17 & 3.24 & 1.20 & 48 & .09 & -0.84 & 0.40 & .90 \\
\hline 21 & 25 & 3.08 & 1.32 & 3.20 & 1.32 & 48 & .02 & -0.32 & 0.75 & .71 \\
\hline 22 & 25 & 2.96 & 1.10 & 3.20 & 1.12 & 48 & .17 & -0.77 & 0.45 & .89 \\
\hline 23 & 25 & 3.00 & 1.12 & 3.20 & 1.11 & 48 & .16 & -0.63 & 0.53 & .93 \\
\hline
\end{tabular}

Structure Validity. Exploratory and Confirmatory Factor Analyses were conducted to determine the construct validity of the scale. Based on the view of MacCallum, Widaman, Zhang, and Hong (1999), stating that "the sample in the range of 100-200 can be accepted when the factors are clear", the first application was carried out on 140 people and 116 data were analyzed. As a result of this analysis, a scale consisting of 3 factors with 20 items emerged. The Cronbach's Alpha coefficient for the whole scale was found to be 0.928 . When the reliability coefficient value is done after EFA is examined, it is seen that it is within acceptable limits. However, the number of samples was increased to 485 , based on the opinion that the difference in the number of factors and items between the original scale and the Turkish form may be due to the fact that three items are not included in the scale in line with the opinions of the experts of education management, the small sample size, factor loadings and model fit indexes. For the sample size, Nunnally (1978)Nunnally (1978) suggests 10 times the number of items. Tabachnick and Fidell (2013) stated that at least 300 samples are a good sample for factor analysis. Considering these data in the literature, it can be said that the sample value of 485 is suitable for EFA.

Later, 35 of the data collected from the study group consisting of 485 people were excluded from the analysis due to the high number of unanswered items, and 450 data were found to be sufficient for construct validity studies in the adaptation process of the Reputation Scale. For item analysis, item-total correlations and the significance levels of the differences between the means of the lower/upper $27 \%$ groups were checked (Büyüköztürk, 2010; Yılmaz, 2020). 
Table 3. KMO and Bartlett's Test

\begin{tabular}{llc}
\hline Kaiser-Meyer-Olkin Measure of Sampling Adequacy. & $\mathbf{. 9 5}$ \\
\hline \multirow{3}{*}{ Bartlett's Test of Sphericity } & Approx. Chi-Square & 3920.49 \\
& df & 253 \\
& p & .000 \\
\hline
\end{tabular}

Bartlett's sphericity test was conducted, and it was determined that the data were suitable for factor analysis (Table 3).

Table 4. Item-total correlations of the Reputation Scale and independent group t-test results for the differences between $27 \%$ lower - upper groups

\begin{tabular}{|c|c|c|c|c|c|}
\hline Item & $\bar{x}$ & Ss & $\begin{array}{l}\text { Item-total } \\
\text { Correlation }\end{array}$ & $\mathbf{t}$ & $p$ \\
\hline 1 & 3.05 & 1.23 & 0.58 & -46.24 & .000 \\
\hline 2 & 3.12 & 1.06 & 0.65 & -42.63 & .000 \\
\hline 3 & 3.15 & 1.07 & 0.50 & -45.14 & .000 \\
\hline 4 & 3.13 & 1.04 & 0.59 & -45.14 & .000 \\
\hline 5 & 3.00 & 1.31 & 0.54 & -51.03 & .000 \\
\hline 6 & 2.81 & 1.27 & 0.51 & -51.02 & .000 \\
\hline 7 & 3.10 & 1.09 & 0.54 & -44.54 & .000 \\
\hline 8 & 2.99 & 1.12 & 0.59 & -44.12 & .000 \\
\hline 9 & 3.15 & 1.08 & 0.52 & -38.57 & .000 \\
\hline 10 & 3.04 & 1.07 & 0.53 & -44.21 & .000 \\
\hline 11 & 3.15 & 1.12 & 0.62 & -44.11 & .000 \\
\hline 12 & 3.13 & 1.112 & 0.59 & -44.18 & .000 \\
\hline 13 & 3.12 & 1.11 & 0.56 & -44.38 & .000 \\
\hline 14 & 3.29 & 1.15 & 0.52 & -43.55 & .000 \\
\hline 15 & 3.26 & 1.17 & 0.57 & -45.60 & .000 \\
\hline 16 & 3.33 & 1.15 & 0.47 & -38.31 & .000 \\
\hline 17 & 3.17 & 1.15 & 0.61 & -45.48 & .000 \\
\hline 18 & 2.96 & 1.21 & 0.61 & -46.42 & .000 \\
\hline 19 & 3.01 & 1.17 & 0.57 & -45.01 & .000 \\
\hline 20 & 3.08 & 1.21 & 0.60 & -45.86 & .000 \\
\hline 21 & 3.11 & 1.23 & 0.67 & -48.50 & .000 \\
\hline 22 & 2.85 & 1. 20 & 0.58 & -46.62 & .000 \\
\hline 23 & 3.15 & 1.20 & 0.61 & -46.69 & .000 \\
\hline
\end{tabular}

When Table 4 is examined, it is seen that the item-total correlations for all items in the Reputation scale vary between 0.47 and 0.67 , and the $t$-values $(p<001)$ are significant. Accordingly, it can be said that the items in the scale have high validity, exemplify similar behaviors, and the internal consistency of the scale is high. While the item with the lowest correlation coefficient is $16(0.47)$, the item with the highest correlation coefficient is 21 (0.67).

As a result of EFA done for the 23-item form of the scale, it was found that $\mathrm{KMO}=.95$, Bartlett=3920, and $p=.000$ (Table 3). These values show that the number of samples in the data set is sufficient, and multivariate normal distribution is provided. When the diagonal correlations in the correlation matrix were examined, it was seen that the lowest value was in the 15th item (0.93), and all items could be included in EFA because there was no value below 50. When the common variances of each item were examined, it was found that the fifth item (0.38) had the lowest contribution to the common variance, and the 16th item (0.66) had the highest 
contribution (Table 5). The original scale consisting of 23 items and seven factors was structured as 23 items and five factors as a result of EFA (Table 4).

Table 5. Oblimin rotated pattern components matrix of RepTrak scale form for higher education institutions

\begin{tabular}{|c|c|c|c|c|c|c|}
\hline \multirow[b]{2}{*}{ Item No } & \multicolumn{5}{|c|}{ Factors } & \multirow{2}{*}{$\begin{array}{l}\text { Common } \\
\text { Variance }\end{array}$} \\
\hline & 1 & 2 & 3 & 4 & 5 & \\
\hline 19 & .731 & -.023 & .010 & .102 & -.059 & .58 \\
\hline 22 & .717 & -.138 & .106 & .024 & .138 & .61 \\
\hline 18 & .610 & .005 & .085 & .215 & -.086 & .56 \\
\hline 23 & .609 & .150 & -.008 & -.113 & .331 & .63 \\
\hline 20 & .576 & .214 & .191 & -.043 & -.083 & .55 \\
\hline 21 & .375 & .330 & .095 & -.032 & .283 & .58 \\
\hline 15 & .154 & .688 & .021 & -.084 & .173 & .62 \\
\hline 14 & -.091 & .627 & .097 & .215 & .002 & .55 \\
\hline 16 & -.155 & .568 & .489 & .054 & -.202 & .66 \\
\hline 17 & .241 & .501 & -.047 & .059 & .233 & .54 \\
\hline 3 & .029 & .010 & .837 & .017 & -.100 & .71 \\
\hline 1 & .151 & .035 & .615 & -.067 & .260 & .61 \\
\hline 2 & .200 & -.051 & .511 & .177 & .200 & .60 \\
\hline 4 & .185 & .104 & .370 & .135 & .157 & .45 \\
\hline 10 & -.102 & -.059 & .088 & .744 & .174 & .60 \\
\hline 8 & .086 & -.079 & .136 & .667 & .047 & .57 \\
\hline 9 & .028 & .107 & -.055 & .590 & .139 & .46 \\
\hline 12 & .154 & .286 & -.109 & .556 & -.028 & .56 \\
\hline 11 & .316 & .024 & .140 & .505 & -.147 & .57 \\
\hline 13 & .348 & .291 & -.069 & .403 & -.246 & .55 \\
\hline 7 & .015 & .198 & .002 & .197 & .606 & .58 \\
\hline 6 & .071 & -.069 & .142 & .238 & .564 & .54 \\
\hline 5 & .025 & .210 & .171 & .197 & .349 & .42 \\
\hline
\end{tabular}

As seen in Table 5, no overlapping items were found as a result of the oblimin rotation. Explanation power among the items in all factors is more than $10 \%$. As a result of the analysis, the factor named as Leadership-Performance dimension consisted of 6 items, the factor named as social responsibility dimension consisted of 4 items, the factor named as product-service dimension consisted of 4 items, the factor named as workplace-management dimension consisted of 6 items, and the factor named the innovativeness dimension consisted of 3 items. The factor loads of the items in the first factor were found to vary between 0.73 and 0.38 , the factor loads of the items in the second factor between 0.69 and 0.50 , the factor loads of the items in the third factor between 0.84 and 0.37 , the factor loads in the fourth factor between 0.74 and 0.40 and the factor loads of the items on the fifth factor between 0.61 and 0.35 (Table 5). After individually calculating factor loadings of the items in each factor, the explanatory power of each factor for the total variance was calculated.

Table 6. Percentages of factor loadings on explaining the total variance

\begin{tabular}{|c|c|c|c|}
\hline \multirow{3}{*}{$\begin{array}{l}\text { Factor } \\
1\end{array}$} & \multicolumn{3}{|c|}{ Initial eigenvalues Factor Loads } \\
\hline & \multirow{2}{*}{$\begin{array}{l}\text { Total } \\
8.805\end{array}$} & \multicolumn{2}{|c|}{ Variance $\%$ Cumulative $\%$} \\
\hline & & 38.281 & 38.281 \\
\hline 2 & 1.165 & 5.063 & 43.344 \\
\hline 3 & 1.142 & 4.964 & 48.308 \\
\hline 4 & 1.037 & 4.508 & 52.816 \\
\hline 5 & .953 & 4.143 & 56.959 \\
\hline 6 & .831 & 3.612 & 60.571 \\
\hline 7 & .767 & 3.336 & 63.906 \\
\hline
\end{tabular}


In the exploratory factor analysis, the direct oblimin rotation method (Tabachnick \& Fidell, 2013), which is recommended to be used in cases where the correlation between factors is thought to be high, was used. As a result of the exploratory factor analysis, a scale consisting of 5 factors with 23 items emerged. The total variance explained in five factors, and 23 items were found to be 56.96 . The percentage of explanation of total variance by the first factor with 6 items was 38.28, the percentage of explanation of total variance by the second factor with four items was 5.06, the percentage of explanation of the total variance of the third factor with four items was 4.96, the percentage of explanation of the total variance of the fourth factor with 6 items was 4.51 and the explanation percentage of the total variance of the fifth factor with 3 items was found to be 4.14 . The factor structure for this process can be seen in the scree plot in Figure 1. The factors under which the items in the original scale were placed as a result of the adaptation are shown in Appendix 1.

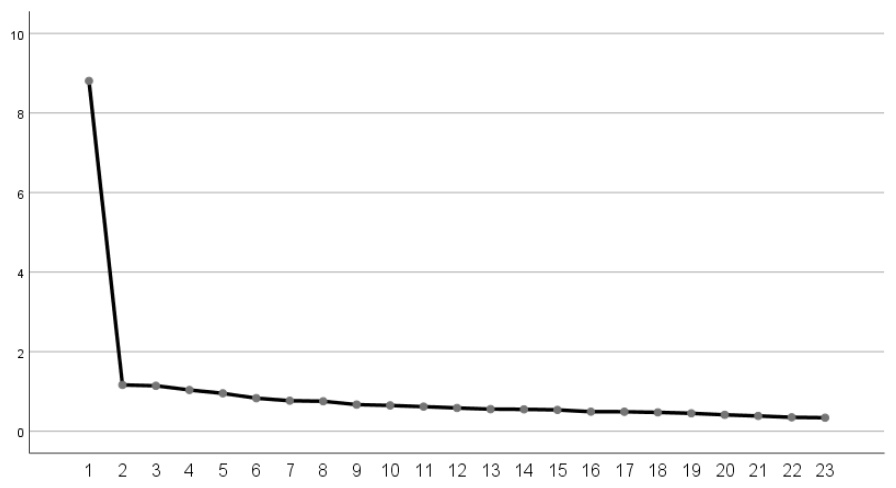

Figure 1. RepTrak Scree Plot

The Cronbach's alpha reliability coefficients of the five-factor measurement tool formed as a result of EFA were calculated. As a result of this calculation, the reliability coefficient of the scale as a whole was found to be 0.93 . The reliability coefficients of the first factor of the scale were found to be 0.83 , of the second factor was 0.73 , the third factor was 0.76 , the fourth factor was 0.80 , and the fifth factor was 0.618 . Correlations between dimensions are given in Table 7 .

Table 7. Correlation Matrix Between Factors

\begin{tabular}{lcccccc}
\hline Factors & $\begin{array}{c}\text { Leadership and } \\
\text { Performance }\end{array}$ & $\begin{array}{c}\text { Social } \\
\text { responsibility }\end{array}$ & Product & Service & Governance and & \multicolumn{2}{c}{ Total } \\
& Workplace & Innovation & Reputation \\
\hline Leadership and Performance & 1.000 & .379 & .373 & .442 & .301 & .886 \\
Social responsibility & .379 & 1.000 & .337 & .380 & .164 & .800 \\
Product Service & .373 & .337 & 1.000 & .362 & .223 & .817 \\
Governance and Workplace & .442 & .380 & .362 & 1.000 & .239 & .860 \\
Innovation & .301 & .164 & .223 & .239 & 1.000 & .771 \\
Total Reputation & .886 & .800 & .817 & .860 & .771 & 1.00 \\
\hline
\end{tabular}

As a result of the correlation matrix created, the correlation values between the factors were found to have values ranging from 0.44 to 0.16 . In addition, when the correlation between each factor and the whole scale was analyzed by calculating the Pearson correlation coefficient, it was found that there were values varying between 0.77 and 0.88 (Table 7).

As a result of these analyses, it was decided that the scale was reliable at the factor level, too. It was decided to conduct an advanced confirmatory factor analysis (CFA) to support these processes. At this stage, data were collected again from a different sample group of 300 people for the study.

The Kurtosis value was found to be 35.04, and the $\mathrm{Cr}$ value was found to be 8.95 in the last study performed on 300 samples, named Model 1 in Table 7. Because the CR value is greater than 5, it does not meet 
the assumption of the normality of the multiple distributions (Byrne, 2016). In Model 2, Mahalanobis values were calculated, and 36 extreme values below 0.05 were removed, and a multiple normality test was performed again (Gao, Mokhtarian, \& Johnston, 2008). As a result of this test, it was seen that the multivariate normality assumption ( $\mathrm{Cr}=2.86$ ) was fulfilled (Table 7). Finally, in Model 3, the values of the goodness of fit that occurred after the modification specified in Table 8 were given.

Table 8. The goodness of Fit Values

\begin{tabular}{llllllllllllll}
\hline Model & $\mathbf{n}$ & Kurtosis & c.r & $\boldsymbol{x}^{2}$ & $\mathbf{d f}$ & $\mathbf{p}$ & $\boldsymbol{\varkappa}^{2} / \mathbf{d f}$ & $\mathbf{p}$ & $\mathbf{G F I}$ & $\mathbf{C F I}$ & \multicolumn{2}{l}{ RMSEA RMR } & SRMR \\
\hline 1 & 300 & 35.04 & 8.94 & 475.73 & 221 & 0.00 & 2.15 & 0.00 & 0.88 & 0.91 & 0.06 & 0.05 & 0.05 \\
\cline { 2 - 12 } 2 & 264 & 11.97 & 2.86 & 515.87 & 225 & 0.00 & 2.29 & 0.00 & 0.85 & 0.88 & 0.07 & 0.05 & 0.05 \\
\cline { 2 - 12 } 3 & 264 & 11.97 & 2.86 & 470.62 & 222 & 0.00 & 2.12 & 0.00 & 0.87 & 0.90 & 0.06 & 0.05 & 0.05 \\
\hline
\end{tabular}

When the modification indexes that emerged as a result of CFA were examined, it was seen that items 8 and 10, items 18 and 19 and items 22 and 23 should be handled together and the model should be changed (Table 9). The modification was made gradually, starting with the items that provided the greatest change in the value of c2. It was observed that the goodness of fit values improved even more after the three modifications indicated in Table 9 (Table 9). Accordingly, it is seen that there was a $16 \%$ change in the first modification, $13 \%$ in the second and $11 \%$ in the last modification.

Table 9. Modification Values

\begin{tabular}{|c|c|c|c|}
\hline Item & & Change & $\%$ \\
\hline $\mathrm{e} 22$ & $<-->$ e23 & 18.68 & .16 \\
\hline e18 & <--> e19 & 13.80 & .13 \\
\hline e8 & $<-->$ e10 & 10.66 & .11 \\
\hline
\end{tabular}

Based on the literature, when Model 3 is analyzed in Table 7, where the fit values of the model are within acceptable limits when the goodness of fit values of CFA are examined, the acceptability of all values are seen. When Model 3 is examined in Table 7 when the goodness of fit values of CFA are examined, it is seen that all values are acceptable, that $\varkappa 2 / \mathrm{df}$ value is below $5, \mathrm{CFI}$ is greater than 0.90 , the fit values of the model are within acceptable limits based on RMSEA and RMR literature. $\varkappa 2 / \mathrm{df}$ value below 5, CFI greater than 0.90, RMSEA and RMR values below 0.08 may indicate acceptable goodness of fit.

According to Sümer (2000), it is stated that an RMSA value below .05 is an indicator of a perfect fit. Hu and Bentler (1999) state that a value below .05 is an indicator of a good fit. Steiger (1990), Browne and Mels (1990), Browne and Cudeck (1992) have stated that the RMSEA value below .05 indicates that the model is compatible. In addition, Browne and Cudeck (1992) stated that RMSEA value being between .05 - .08 indicates acceptable fit and a value above 10 indicates poor fit. Although GFI and CFI fit indices are not at the desired values, it can be seen in Table 7 that there are values very close to the desired values. However, when evaluated with other goodness of fit values ( $2 / \mathrm{df}$, RMR, SRMR and RMSEA) as a whole, it can be said that they are acceptable values. The value of $\chi 2 / \mathrm{df}$ being below 5 or, according to some sources, below three is seen as an indicator of good fit (Şimşek, 2007; Tabachnick \& Fidell, 2013). In large samples, $\chi 2 / \mathrm{df}$ can be used as a criterion for sufficiency (Çokluk, Şekercioğlu, \& Büyüköztürk, 2012). However, in addition to $\chi 2 / \mathrm{df}$, it is beneficial to consider other fit indices (Çelik \& Yılmaz, 2013). As a result of the modifications and analyzes, it was found that the values of the goodness of fit were at acceptable levels, as can be seen in the literature (Table 7). Hu and Bentler (1999) state that a value below .05 is an indicator of a good fit. Steiger (1990), Browne and Mels (1990), Browne and Cudeck (1992) have stated that the RMSEA value below .05 indicates that the model is compatible. In addition, Browne and Cudeck (1992) stated that an RMSEA value between .05 - .08 indicates acceptable fit, while a value above 10 indicates poor fit. Although GFI and CFI fit indices are not at the desired values, it can be seen in Table 7 that there are values very close to the desired values. However, when evaluated 
with other goodness of fit values ( $2 / \mathrm{df}, \mathrm{RMR}$, SRMR and RMSEA) as a whole, it can be said that they are acceptable values. According to some sources, the value of $\chi 2 / \mathrm{df}$ is below 5 or, according to some sources, below three is seen as an indicator of good fit (Şimşek, 2007; Tabachnick \& Fidell, 2013). In large samples, $\chi 2 / \mathrm{df}$ can be used as a criterion for sufficiency (Çokluk et al., 2012). However, in addition to $\chi 2 / \mathrm{df}$, it is beneficial to consider other fit indices (Çelik \& Y1lmaz, 2013). As a result of the modifications and analyses, it was found that the values of the goodness of fit were at acceptable levels, as can be seen in the literature (Table 7).

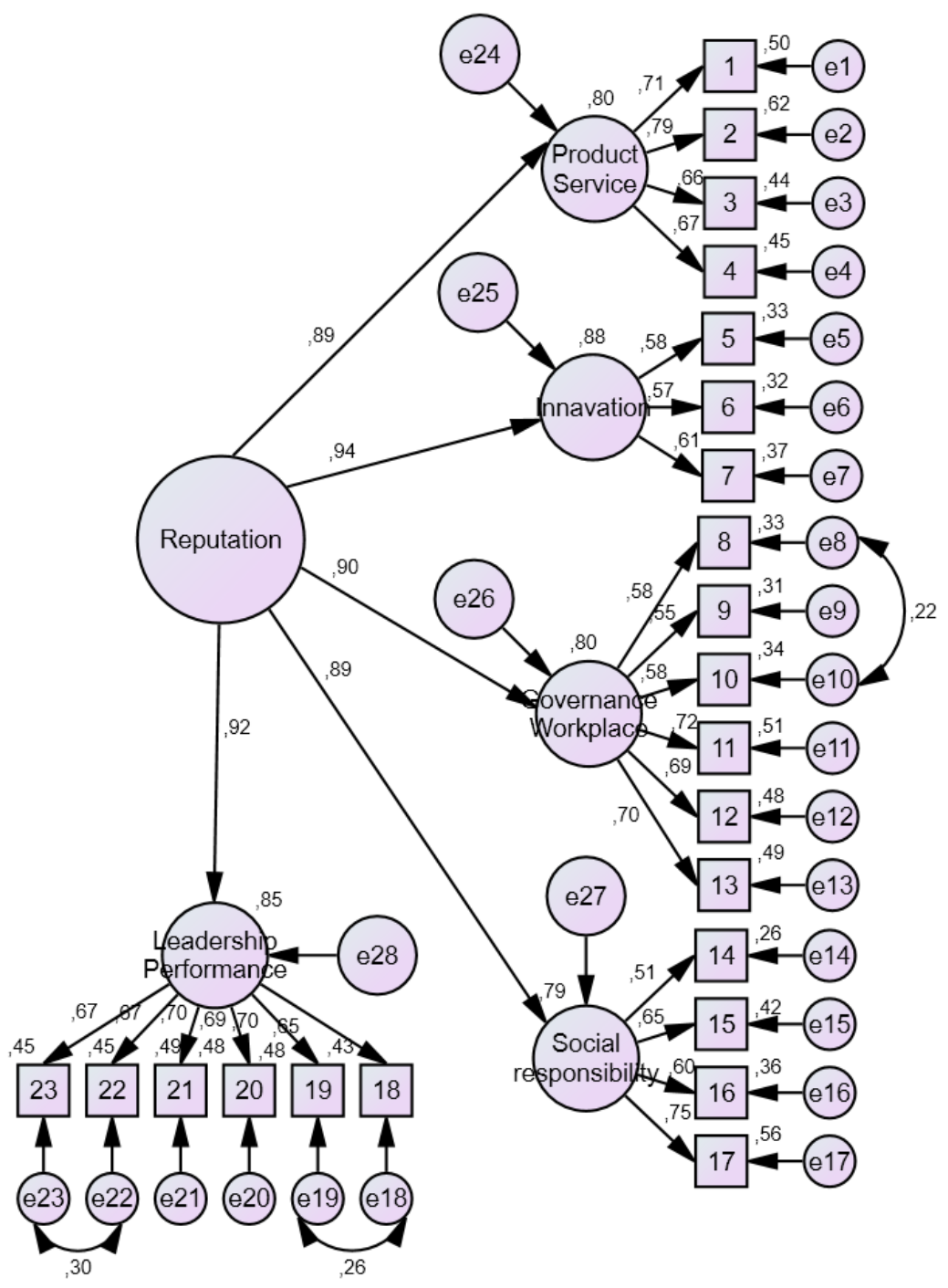

Figure 2. Path Graph

\section{Conclusion, Discussion and Recommendations}

Corporate reputation affects all institutions in today's societies where competition is increasing day by day. Educational institutions are also among the organizations most affected by this competitive environment. The reputation of both primary and secondary education institutions, and universities, which are education and science production institutions, are questioned by different stakeholders at the national and global level. The stakeholders of these institutions take into account their corporate reputation by conducting research in various ways in their preferences. Therefore, this study aimed to adapt the RepTrak scale, which has been adapted to different countries and various organizations before, to higher education institutions of Turkey. As 
a result of the adaptation of the scale to the educational institutions, originally consisting of 7 factors and 23 items, it dropped to 5 factors (Appendix). When any other studies in the literature are examined, it is seen that the scale is widely used in international studies and in many different cultures like Italy, Spain, Thailand, USA, China, Portugal, Greece, Great Britain and Turkey (Christakou \& Klimis, 2014; Fombrun \& Pan, 2006; Luisa et al., 2018; Pitpreecha, 2013; Ramalho \& Matos Resende, 2016; Ruiz et al., 2014a, 2014b; Ruiz et al., 2016; Ural \& Erim, 2010).

The scale, originally consisting of 7 factors and 23 items, as a result of the adaptation to the educational institutions, having dropped to 4 factors, has been compared with the studies in the literature. As a result of the exploratory factor analysis in the study of a study group size of 116 at the first stage of scale adaptation conducted by M. Ergün (2017), the reliability coefficient was found to be 0.928 with three factors. As a result of this comparison, it was seen that similar results were obtained in some studies. In the study conducted by Pitpreecha (2013) in Thailand, the Cronbach alpha coefficient of the scale was found to be 0.95 . It has been found that only five of the seven factors have the ability to explain corporate reputation. The strongest factor was found to be the product-service factor ( $37 \%$ explanatory power). Similarly, in the study conducted by Duygun and Menteş (2015), Rep Trak's corporate reputation measurement tool was used, and the reliability coefficient of this tool was reported as alpha $=0.91$. Although the original scale had seven factors, five factors were formed as a result of factor analysis in the study. Vidaver-Cohen (2007) suggested that the Rep Trak measurement tool can be used to measure the reputation of business schools. However, she proposed an 8factor and 24-item scale by separating product-service factors. She stated that measuring the reputation of business schools is much more complicated than other organizations. Inversini, Marchiori, Dedekind, and Cantoni (2010) calculated the corporate reputation measurement tool (RepTrak) as 16 items, and four factored in their study in organizations in the tourism sector. In the study conducted by Fombrun et al. (2015) on five different stakeholder groups from different sectors and different countries, seven dimensions of the Rep Trak measurement tool were tested with exploratory factor analysis. As a result of the analysis, the innovation dimension of the scale was found to be the factor with the lowest coefficient of Cronbach alpha $=0.84$ in the health sector. The product service dimension has emerged in the insurance sector with the highest coefficient of Cronbach alpha $=0.96$ (Fombrun et al., 2015). A reliability coefficient of 0.70 was found in other sectors and dimensions. Five studies, one of which is qualitative, were conducted on different stakeholder groups by Ponzi et al. (2011). The data obtained from these studies are as follows: Cronbach's alpha coefficient of the second study was found to be 0.96 , the Cronbach's alpha coefficient of the third study was 0.95 , the Cronbach's alpha coefficient of the fourth study was 0.97 , and the Cronbach's alpha coefficient of the fifth study was 0.93 (Ponzi et al., 2011). In the study conducted by Abdullah and Abdul Aziz (2013) in Malaysia, the effects of corporate social responsibility initiatives on corporate reputation were examined. As a result of this study, it was found that social responsibility projects affect corporate reputation. This finding can be accepted as an indicator of the fact that social responsibility is a sub-dimension of corporate reputation. As a result of the confirmatory factor analysis, it is seen that corporate social responsibility initiatives are one of the essential dimensions of corporate reputation (Abdullah \& Abdul Aziz, 2013). It has been found that corporate social responsibility initiatives have the ability to explain the corporate reputation by 24\% (Abdullah \& Abdul Aziz, 2013).

Although there was no change in the number of items of the scale in this study, the number of factors dropped to five in the version adapted to Turkish and higher education institutions of the scale, which originally consisted of 7 factors. The reason for this was that the leadership and performance dimensions of the scale were combined in one factor, the management and workplace dimensions were also combined in one factor, and the innovation and product/service dimensions remained the same as the original scale. Although the social responsibility dimension remained the same, the 17th item in the leadership dimension was found in this dimension. Although the performance dimension of the organizations producing goods is determined depending on the financing of the organization (Donaldson \& Preston, 1995; Waddock \& Graves, 1997; Walsh 
et al., 2003), since this study adapts for educational institutions, the fact that it is preferred among organizations in the sector for service-producing organizations, that the quality of the service is high, its ability to construct the future is related to how it is evaluated by the perceptions of stakeholders constitute the performance dimension of the scale.

In some studies in the literature, confirmatory factor analysis was performed for the same scale, and similar goodness of fit indices was found (Duygun \& Menteş, 2015; M. Ergün, 2017; Fombrun et al., 2015; Ponzi et al., 2011).

In this study, the RepTrak scale used in the international arena as a corporate reputation measurement tool has been adapted into Turkish in order to measure the reputation of higher education institutions in Turkey. As a result of the exploratory and confirmatory factor analyses, the 23-item five-factor scale was made ready for the use of both higher education institution administrators and academicians. While collecting data with this scale, collecting data from both internal and external stakeholders of higher education institutions will provide more reliable data on the subject under investigation.

By using this scale, the researchers can measure the reputation of different higher education institutions. Relationships with different variables related to reputation can be revealed by using different scales with this scale. Validity and reliability studies of the same scale can be conducted in primary and secondary schools affiliated with the Ministry of National Education. Every university can take measures to increase its reputation by using the scale. 


\section{Appendix}

Distribution of the items of the adapted scale according to the factors in Table 4.

Explanations made in italic letters in brackets show the dimensions of the original scale.

\section{Faktör 3: Ürün/hizmet}

1. Yüksek kaliteli eğitim ve mezunlar sunar (Ürün-hizmet)

2. Yapılan eğitim harcamalarının karşıllğını verir (Ürün-hizmet)

3. Verdiği eğitimin ve mezunlarının arkasında durur (Ürün-hizmet)

4. İç ve dış paydaşların ihtiyaçlarını karşılar (Ürün-hizmet)

\section{Faktör 5: Yenilik}

5. Yenilikçi bir eğitim kurumudur (Yenilik)

6. Türkiye'de ilk olan bölümlere sahiptir (Yenilik)

7. Değişikliğe çabuk uyum sağlar (Yenilik)

\section{Faktör 4: Yönetim ve işyeri}

8. Çalışanlarını adil bir şekilde ödüllendirir (İşyeri)

9. Çalışanların sağlık ve refahı için endişelenir (İşyeri)

10 İşyerinde eşit fırsatlar sunar (Işsyeri)

11. Yönetim açık ve şeffaftır (Yönetim)

12. Yönetim etik davranır (Yönetim)

13. Yönetim eğitim sürecinde tüm paydaşlara adil davranır (Yönetim)

\section{Faktör 2: Sosyal sorumluluk (vatandaşlık)}

14. Çevreyi korumak için sorumlu davranır (Sosyal sorumluluk)

15. Çevre konusunda toplum üzerinde olumlu bir etkisi vardır (Sosyal sorumluluk)

16. Çevreci fikirleri destekler (Sosyal sorumluluk)

17. (Çevre konusunda) İyi organize olmuş bir eğitim kurumudur (Liderlik)

\section{Faktör 1: Liderlik ve performans}

18. Güçlü ve çekici bir lideri vardır (Liderlik)

19. Mükemmel yöneticilere sahiptir (Liderlik)

20. Gelecek için açık bir vizyona sahiptir (Liderlik)

21. Eğitim almada tercih edilen kurumdur (Performans)

22. Mezunlar iş bulmada/bir üst öğrenim kurumuna gitmede sıkıntı çekmez (Performans)

23. Gelecek vadeden bir eğitim kurumudur (Performans) 


\section{REFERENCES}

Abdullah, Z., \& Abdul Aziz, Y. (2013). Institutionalizing corporate social responsibility: effects on corporate reputation, culture, and legitimacy in Malaysia. Social Responsibility Journal, 9(3), 344-361. doi:10.1108/SRJ-05-2011-0110

Açıkgöz, F. Y., \& Karakaya, Ç. (2018). Akademik örgütlerde itibar algısı: Akdeniz üniversitesi'nin iç ve dış paydaşları üzerine bir araştırma. Akdeniz Iletisim(30), 191-217.

Aydem-Çiftçioğlu, B. (2008). Kurumsal itibarın çalışanların örgütsel bağlllıklarn üzerindeki etkisi ve bir uygulama. (Unpublished Doctoral Thesis). Uludağ Üniversitesi, Bursa.

Ayyildiz, P., Yilmaz, A., \& Baltaci, H. S. (2021). Exploring digital literacy levels and technology integration competence of Turkish academics. International Journal of Educational Methodology, 7(1), 15-31. doi:https://doi.org/10.12973/ijem.7.1.15

Balay, R., Kaya, A., \& Yıldırım, M. (2017). Yükseköğretim kurumlarında itibar yönetimi ölçeğinin geliştirilmesi. Ahi Evran Üniversitesi Kırşehir Eğitim Fakültesi Dergisi, 18(3), 645-667.

Barnett, M. L., Jermier, J. M., \& Lafferty, B. A. (2006). Corporate reputation: The definitional landscape. Corporate reputation review, 9(1), 26-38.

Barnett, M. L., \& Pollock, T. G. (2012). The Oxford handbook of corporate reputation. Oxford: Oxford University Press.

Baygül-Özpınar, Ş. B. (2008). Kurumsal itibarın ölçümü: Türkiye'ye yönelik ölçek geliştirme çalışması. (Unpublished Doctoral Thesis). Anadolu Üniversitesi Eskişehir.

Bromley, D. (2002). Comparing corporate reputations: League tables, quotients, benchmarks, or case studies? Corporate reputation review, 5(1), 35-50.

Browne, M. W., \& Cudeck, R. (1992). Alternative ways of assessing model fit. Sociological methods $\mathcal{E}$ research, 21(2), 230-258.

Browne, M. W., \& Mels, G. (1990). Ramona user's guide, Columbus: Department of psychology. Ohio State University.

Büyüköztürk, Ş. Çakmak, E. Akgün, Ö. E. Karadeniz, Şirin ve Demirel, F. (2016). Eğitimde bilimsel araştırma yöntemleri. 26. Bask1, Ankara: Pegem Akademi.

Büyüköztürk, Ş. (2010). Sosyal bilimler için veri analizi el kitabı: İstatistik, araştırma deseni, SPSS uygulamaları ve yorum (4th ed.). Ankara: Pegem Akademi Yayıncilik.

Byrne, B. M. (2016). Structural equation modeling with AMOS: Basic concepts, applications, and programming (multivariate applications series) (3rd ed.). New York: Taylor \& Francis Group.

Cabral, L. (2016). Media exposure and corporate reputation. Research in Economics, 70(4), 735-740.

Çabuk, D. (2017). Türkiye'de faaliyet gösteren sivil toplum kuruluşlarının itibarını ölçmek. Global Media Journal: Turkish Edition, 8(15), 233-258.

Casado, A. M., Peláez, J. I., \& Cardona, J. (2014). Managing corporate reputation: A perspective on the Spanish market. Corporate reputation review, 17(1), 46-63.

Çelik, H. E., \& Yılmaz, V. (2013). LISREL 9.1 ile yapısal eşitlik modellemesi: Temel kavramlar, uygulamalar, programlama. Ankara: Anı Yayıncilik.

Christakou, E. R., \& Klimis, G.-M. (2014). Measuring the e-word of mouth reputation and its influence on financial performance. Paper presented at the European Conference on Social Media, Brighton, UK.

Cianci, A. M., \& Kaplan, S. E. (2010). The effect of CEO reputation and explanations for poor performance on investors' judgments about the company's future performance and management. Accounting, Organizations and Society, 35(4), 478-495.

Çınar, E., \& Basim, H. N. (2019). Örgütsel itibarın örgütsel özdeşleşmeye etkisinde benlik saygısı ve sosyal rol kimliğinin düzenleyici rolü. Business and Economics Research Journal, 10(1), 187-202. 
Çokluk, Ö., Şekercioğlu, G., \& Büyüköztürk, Ş. (2012). Sosyal bilimler için çok değişkenli istatistik, SPSS ve LISREL uygulamaları, . Ankara: Pegem.

Davis, G. F. (2005). New directions in corporate governance. Annual review of sociology, 31, 143-162.

Dawar, N., \& Parker, P. (1994). Marketing universals: Consumers' use of brand name, price, physical appearance, and retailer reputation as signals of product quality. Journal of Marketing, 58(2), 81-95.

De Roeck, K., Maon, F., \& Lejeune, C. (2013). Taking up the challenge of corporate branding: an integrative framework. European Management Review, 10(3), 137-151.

Devers, C. E., Dewett, T., Mishina, Y., \& Belsito, C. A. (2009). A general theory of organizational stigma. Organization Science, 20(1), 154-171.

Dinçel, G. (2012). Kurumsal itibar ile örgütsel kıvanç, duygusal bağhllık ve örgütsel vatandaşlık davranışı arasındaki ilişkilerin incelenmesi: Bir araştırma. (Unpublished doctoral thesis). Kocaeli Üniversitesi Kocaeli.

Donaldson, T., \& Preston, L. E. (1995). The stakeholder theory of the corporation: Concepts, evidence, and implications. Academy of management Review, 20(1), 65-91.

Dowling, G. R. (2000). Creating corporate reputations: Identity, image and performance. New York: Oxford University Press.

Dowling, G. R. (2016). Defining and measuring corporate reputations. European Management Review, 13(3), 207223.

Duygun, A., \& Menteş, S. A. (2015). The impacts of complaint satisfaction on corporate reputation, negative word-of-mouth communication intention and repurchase intention. Balkan Journal of Social Sciences, 4(8), 120-128.

Ergün, M. (2017). İtibar yönetimi. In S. Özdemir \& N. Cemaloğlu (Eds.), Örgütsel Davranış ve Yönetimi (pp. 149178). Pegem Akademi Yayınları: Ankara.

Ergün, M. (2017). Reptrak corporate reputation measurement tool's adaptation to Turkish. Paper presented at the 26th Uluslararası Eğitim Bilimleri Kongresi, Ankara.

Ergün, M., Akcaoğlu, M. Ö., \& Ünver, N. (2018). Üniversite itibari, markalaşma ve öğrencilerde aidiyet duygusu. In S. Dinçer (Ed.), Değişen Dünyada Eğitim. Ankara: Pegem Akademi Yayıncılık.

Fang, E., Palmatier, R. W., \& Grewal, R. (2011). Effects of customer and innovation asset configuration strategies on firm performance. Journal of marketing research, 48(3), 587-602.

Fraenkel, J. R., Wallen, N. E., \& Hyun, H. H. (1993). How to design and evaluate research in education (Vol. 7). New York: McGraw-hill.

Fombrun, C. J., \& Pan, M. (2006). Corporate reputations in China: How do consumers feel about companies? Corporate reputation review, 9(3), 165-170.

Fombrun, C. J., Ponzi, L. J., \& Newburry, W. (2015). Stakeholder tracking and analysis: The RepTrak® system for measuring corporate reputation. Corporate reputation review, 18(1), 3-24.

Fombrun, C. J., \& Van Riel, C. (1997). The reputational landscape. Corporate reputation review, 1-16.

Gao, S., Mokhtarian, P. L., \& Johnston, R. A. (2008). Nonnormality of data in structural equation models. Transportation Research Record, 2082(1), 116-124.

Geçikli, F., Erciş, M. S., \& Okumuş, M. (2016). An experimental study on components and parametres of corporate reputation: One of the pioneer corporations of Turkey. Atatürk Üniversitesi Sosyal Bilimler Enstitüsü Dergisi, 20(4), 1549-1562.

Hardeck, I., \& Hertl, R. (2014). Consumer reactions to corporate tax strategies: Effects on corporate reputation and purchasing behavior. Journal of business ethics, 123(2), 309-326.

Hu, L. t., \& Bentler, P. M. (1999). Cutoff criteria for fit indexes in covariance structure analysis: Conventional criteria versus new alternatives. Structural equation modeling: a multidisciplinary journal, 6(1), 1-55. 
İnce, A. R., \& Tosun, N. (2015). İç müşteri odaklı kurumsal itibar bileşenlerinin belirlenmesi ve is gören performansına etkisinin değerlendirilmesi üzerine bir araştırma. Kafkas University Faculty of Economics and Administrative Sciences Journal, 6(11), 37-52.

Ingenhoff, D., \& Sommer, K. (2010). Trust in companies and in CEOs: A comparative study of the main influences. Journal of business ethics, 95(3), 339-355.

International Test Commission. (2017). International guidelines on test adaptation. Retrieved from https://www.intestcom.org/files/guideline test adaptation.pdf

Inversini, A., Marchiori, E., Dedekind, C., \& Cantoni, L. (2010). Applying a conceptual framework to analyze online reputation of tourism destinations. Information and communication technologies in tourism 2010, 321332.

Jackson, K. T. (2004). Building reputational capital: Strategies for integrity and fair play that improve the bottom line. Oxford: Oxford University Press.

Kaplan, A. (2018). Kurumsal sosyal sorumluluk ve kurumsal itibar algilamalarının örgütsel özdeşleşme üzerine etkisi. (Unpublished master's thesis). Selçuk Üniversitesi Konya.

Karakaya-Şatır, Ç. (2013). Farklı paydaş algılarının eşzamanlı ölçümü: Kolektif itibar" akademik örgütlerin iç ve dış paydaşlarının algıları üzerine bir araştırma". Akdeniz Iletisim(19), 45-59.

Kennedy, M. T., Chok, J. I., \& Liu, J. (2012). What does it mean to be green? The emergence of new criteria for assessing corporate reputation. In B. M. L. \& T. G. Pollock (Eds.), The Oxford handbook of corporate reputation (pp. 69-93). Oxford: Oxford University Press.

Lange, D., Lee, P. M., \& Dai, Y. (2011). Organizational reputation: A review. Journal of management, 37(1), 153184.

Luisa, P., Valeria, N., \& Nicola, R. (2018). Sustainability reporting as a tool to improve transparency towards stakeholders. Exploring reporting practices in the imaging industry. American Journal of Applied Sciences, 14(12). doi:10.3844/ajassp.2017.1167.1177

MacCallum, R. C., Widaman, K. F., Zhang, S., \& Hong, S. (1999). Sample size in factor analysis. Psychological methods, 4(1), 84 .

Mackiewicz, A. (1993). The economist intelligence unit guide to building a global image. New York: McGraw-Hill Companies.

Mael, F., \& Ashforth, B. E. (1992). Alumni and their alma mater: A partial test of the reformulated model of organizational identification. Journal of organizational Behavior, 13(2), 103-123.

Nunnally, J. C. (1978). Psychometric theory (2nd ed.). New York: McGraw-Hill.

Özalp, İ., Tonus, H. Z., \& Geylan, A. (2010). Paydaşları açısından akademik organizasyonlarda itibar. Organizasyon ve Yönetim Bilimleri Dergisi, 2(1), 99-106.

Petkova, A. (2012). From the ground up: Building young firms' reputations. In T. G. Pollock \& M. L. Barnett (Eds.), The Oxford handbook of corporate reputation (pp. 388-401). Oxford: Oxford University Press.

Pfarrer, M. D., Pollock, T. G., \& Rindova, V. P. (2010). A tale of two assets: The effects of firm reputation and celebrity on earnings surprises and investors' reactions. Academy of Management Journal, 53(5), 1131-1152.

Pitpreecha, R. (2013). Corporate reputation in Thailand: An analysis of indicators. Journal of Public Relations and Advertising, 6(1), 1-16.

Ponzi, L. J., Fombrun, C. J., \& Gardberg, N. A. (2011). RepTrak ${ }^{\mathrm{TM}}$ pulse: Conceptualizing and validating a short-form measure of corporate reputation. Corporate reputation review, 14(1), 15-35.

Ramalho, W., \& Matos Resende, L. (2016). Reputação em serviço público de transporte. Revista Gestão $\mathcal{E}$ Tecnologia, 16(2), 218-237.

Ruiz, B., Esteban, A., \& Gutiérrez, S. (2014a). Determinants of reputation of leading Spanish financial institutions among their customers in a context of economic crisis. BRQ Business Research Quarterly, 17(4), 259-278. 
Ruiz, B., Esteban, A., \& Gutiérrez, S. (2014b). Reputación bancaria durante la crisis económica. Comparación entre las principales entidades financieras desde la perspectiva del cliente. Universia Business Review(43), 16-34.

Ruiz, B., García, J. A., \& Revilla, A. J. (2016). Antecedents and consequences of bank reputation: a comparison of the United Kingdom and Spain. International Marketing Review, 33(6), 781-805. doi:10.1108/IMR-062015-0147

Shapiro, C. (1983). Premiums for high quality products as returns to reputations. The quarterly journal of economics, 98(4), 659-679.

Şimşek, Ö. F. (2007). Yapısal eşitlik modellemesine giriş, temel ilkeler ve LISREL uygulamaları. Ankara: Ekinoks.

Steiger, J. H. (1990). Structural model evaluation and modification: An interval estimation approach. Multivariate behavioral research, 25(2), 173-180.

Sümer, N. (2000). Yapısal eşitlik modelleri: Temel kavramlar ve örnek uygulamalar. Türk Psikoloji Yazılarl, 3(6), 49-74.

Tabachnick, B. G., \& Fidell, L. S. (2013). Using multivariate statistics (6th ed.). NewYork: Pearson.

Tischer, S., \& Hildebrandt, L. (2014). Linking corporate reputation and shareholder value using the publication of reputation rankings. Journal of Business Research, 67(5), 1007-1017.

Tonus, H. Z., \& Tez-Özkan, H. (2013). Farklı paydaşların kurumsal itibarı değerlendirmelerindeki farklılığın Sosyal ve finansal performans algılarıyla ilişkisi. Dumlupinar University Journal of Social Science/Dumlupinar Üniversitesi Soysyal Bilimler Dergisi(35), 1-12.

Ural, E., \& Erim, A. (2010). The impact of public relationship outcomes on the reputation after an organizational change: a case study of a public hospital in Istanbul, Turkey. Paper presented at the 13th International Public Relations Research Conference, Miami.

Van Der Merwe, A. W. A., \& Puth, G. (2014). Towards a conceptual model of the relationship between corporate trust and corporate reputation. Corporate reputation review, 17(2), 138-156.

Van Riel, C., \& Fombrun, C. (2007). Essentials of corporate communication: Implementing practices for effective reputation management. New York, NY: Routledge.

Vidaver-Cohen, D. (2007). Reputation beyond the rankings: A conceptual framework for business school research. Corporate reputation review, 10(4), 278-304.

Waddock, S. A., \& Graves, S. B. (1997). The corporate social performance-financial performance link. Strategic management journal, 18(4), 303-319.

Walker, K. (2010). A systematic review of the corporate reputation literature: Definition, measurement, and theory. Corporate reputation review, 12(4), 357-387.

Walsh, J. P., Weber, K., \& Margolis, J. D. (2003). Social issues and management: Our lost cause found. Journal of management, 29(6), 859-881.

Wartick, S. L. (1992). The relationship between intense media exposure and change in corporate reputation. Business \& Society, 31(1), 33-49.

Weigelt, K., \& Camerer, C. (1988). Reputation and corporate strategy: A review of recent theory and applications. Strategic management journal, 9(5), 443-454.

Weiss, A. M., Anderson, E., \& Maclnnis, D. J. (1999). Reputation management as a motivation for sales structure decisions. Journal of Marketing, 63(4), 74-89.

Wilson, R. (1985). Reputations in games and markets. In A. E. Roth (Ed.), Game-Theoretic Models of Bargaining (pp. 27-62). Cambridge: Cambridge University Press.

Yllmaz, A. (2020). The effect of technology integration in education on prospective teachers' critical and creative thinking, multidimensional 21st century skills and academic achievements. Participatory Educational Research, 8(2), 163-199. 